\title{
Polymineralic orientation analysis of magmatic rocks using Electron Back-Scatter Diffraction: Implications for igneous fabric origin and evolution
}

\author{
I. Romeo $^{\mathrm{a}, *}$, R. Capote $^{\mathrm{b}}$, R. Lunar $^{\mathrm{c}}$, N. Cayzer ${ }^{\mathrm{d}}$ \\ ${ }^{a}$ Deparment of Geology, University of California Davis, One Shields Avenue, Davis, CA 95616-8605 USA \\ ${ }^{b}$ Departament de Geodin mica, Facultad de Ciencias Geológicas, Universidad Complutense de Madrid, 28040 Madrid, Spain \\ ${ }^{\circ}$ Departament de Cristalografia y Mineralogia, Facultad de Ciencias Geológicas, Universidad Complutense de Madrid, 28040 Madrid, Spain \\ - Schøol of GeoSciences, University of Edinburgh, Kings Buildings, West Mains R॰ad, Edinburgh EH9 $3 J W$, United Kingdom
}

\begin{abstract}
Electron Back-Scatter iffaction (EBSD), which provides an easy way of acquiring large numbers of individual crystallo graphic orientation data from different phases, has been applied to the study of mamatic fabrics. Using this technique, the crystallo preferred orientation (CP) of plagioclase, biotite, orthopyroxene, hornblende and quartz in natural tonalites and quartzdiorites (from the Santa lalla Igneous Complex, SW Iberia) deformed during the matic stage have been determined. Plagioclase is the coarser phase defining the main fabric in each sample, whereas biotite can display either the same fabric as plagioclase or a completely different one. The differences between these two phases occur because: (1) smaller phases interact with the larger ones to produce more random orientations, (2) under simple shear, finer phases can completely rotate giving a girdle included in the XZ plane, (3) finer phases can more easily preserve relict fabrics, while the coarser phases are completely reoriented by the last stress tensor. The last phases to crystallize show weak to completely random CPOs (hornblende) or completely random distributions (quartz). The study was completed with a shape preferred orientation analysis using the Intercept Method in order to detect weak magmatic lineations, and nurnerical modelling simulations of theoretically equivalent simple shear situations for each sample.
\end{abstract}

Keywerds: Crystallographic preferred orientation (CPO); Shape preferred orientation (SPO); Magmatic fabrics; Structural geology

\section{Introduction}

Electron Back-Scatter Diffraction (EBSD) is a useful technique for determining crystallegraphic preferred -rientations (CPO) of minerals (Prior et al., 1999). This

\footnotetext{
* Corresponding author. Tel. +15107053055 .

E-mail addresses: romeo@geology.ucdavis.edu (I. Romeo), capote@geo.ucm.es (R. Capote), lunar@geo.ucm.es (R. Iunar), Nicola.Cayzer@ed.ac.uk (N. Cayzer).
}

technique has alløwed the resølution of a number $\bullet$ gelogical problems related to ductile deformation in mylønites (Bestmarm et al., 2004; Ji et al., 2004; LlanaFúnez and Rutter, 2005; amøng others), misørientation analysis (Flierveet et al., 1999; Pennock et al., 2005;

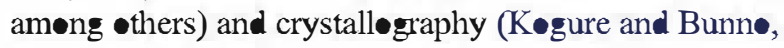
2004; Kameda et al., 2005; among •thers). The potential usefulness of EBSD to study the formation and evelution -f plutenic fabrics was suggested by Prior et al. (1999), but this technique has not previøusly been applied to 


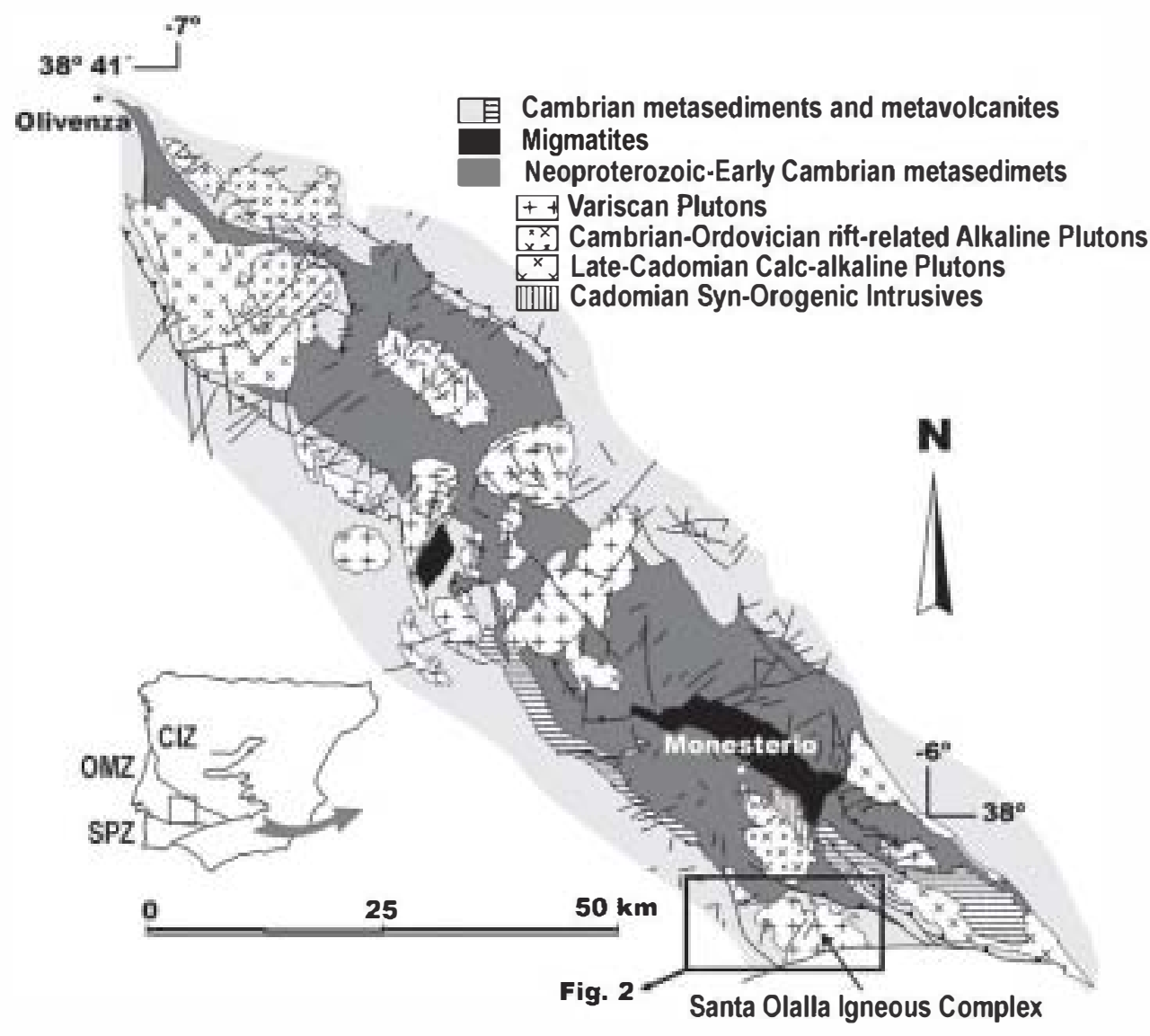

Fig. 1. Geological setting of the study area in the Olivenza-Monesterio antiform. Inset: location in the Iberian Massif (CIZ: Centroiberian Zone, OMZ: Ossa-Morena Zone, SPZ: South Portuguese Zone).

magmatic fabrics in granitoids, althøugh it has been successfully applied to constraint fabrics in basaltic lava flows (Bascou et al., 2005). The capacity of EBSD to yield a large number of precise crystalløgraphic orientations of different mineral phases very rapidly facilitates the determination of CPOs, even when these are weak, as -ccurs in magmatic recks.

Plutonic rocks usually show a preferred orientation - f minerals formed during deformation in the magmatic state (magmatic fabrics, Patersen et al., 1989; Park and Means, 1996; Patersøn et al., 1998) and sømetimes due to sub-sølidus deformation (deformational fabrics, Patersen et al., 1989; Vernon et al, 2004). The formation of magmatic preferred orientation has been studied from analog experiments (Fernandez, 1987; Ildefonse et al., 1992; Arbaret et al., 1996, 2000), numerical modelling (Willis, 1977; Jezek et al., 1994; Arbaret et al., 2000; Iezzi and Ventura, 2002; Launeau, 2004), and natural samples (Blumenfeld, 1983; Blumenfeld and Bouchez, 1988; Benn and Allard, 1989;
Pignotta and Benn, 1999). Numerical modelling shows that the final fabric geometry depends on the type of deformation (cœaxial, non-ceaxial, or a mixture of both) and the geometry of the particles that register the strain. Numerical simulations are based on the formulae developed by Jeffery (1922) that describe the motion -f ellipsøidal rigid particles rotating int a melt under different strain conditions. A development of the Jeffery theory was performed by Arbaret et al. (2000), Femandez et al. (1983), Launeau (2004), and Willis (1977), yielding periodic rotation of the particles deformed by simple shear, and the development of a shape preferred orientation (SPO) periodically parallel to the shear plane. These models differ from the magmatic process, mainly because they do not consider the interactions between adjacent particles (Ildefonse et al., 1992; Tik 1996). The interactions between large and flat crystals deformed under simple shear generate an imbrication or tiling (Blumenfeld, 1983; Blumenfeld and Bouchez, 


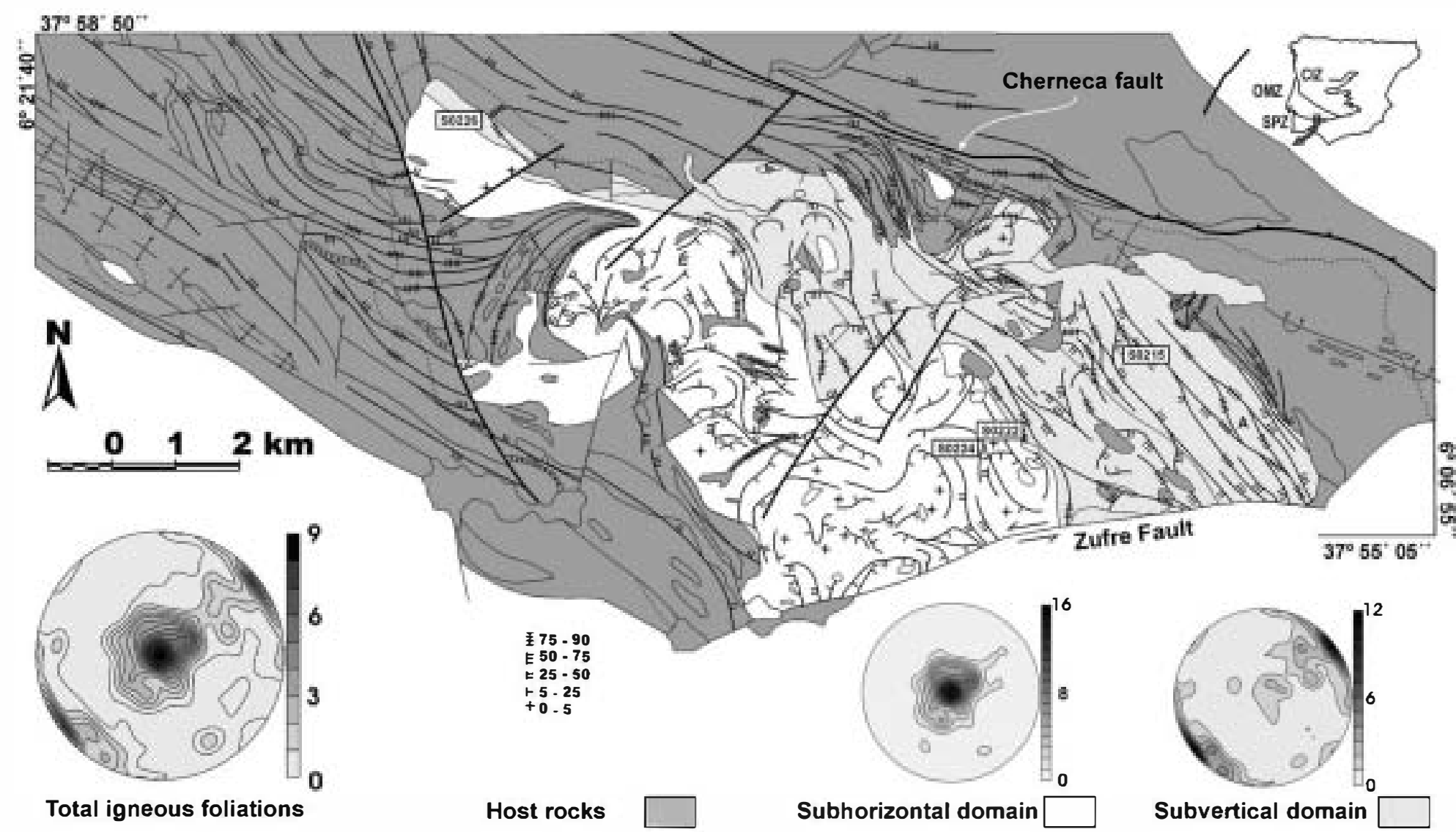

Fig. 2. Magmatic foliation map and stereoplots of the Santa Olalla Igneous Complex. A) Sinistral S-C patterns indicated by the foliation wajectories. The location of the samples analyzed by EBS is shown. 


\section{SPO of sample SO226}

FOLIATION PLANE

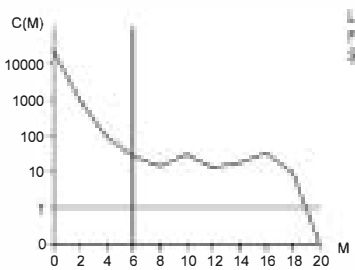

Rose of intercepts $a=27.8712 \mathrm{~cm} \mathrm{~b}=25.6631 \mathrm{~cm}$ $R=1.086$

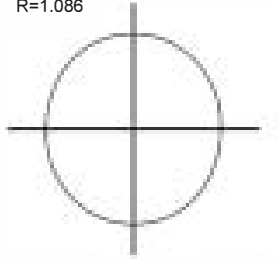

Rose of boundary directions $\mathrm{Nla}=3.003 \mathrm{~cm}^{-1} \quad \mathrm{Nlb}=3.261 \mathrm{~cm}^{-1}$

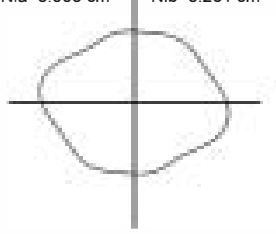

FOLIATION PLANE
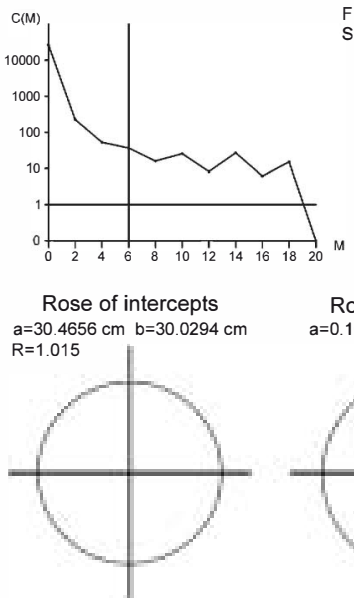

Rose of boundary directions

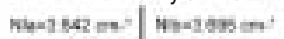

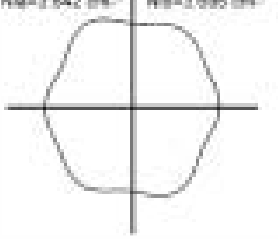

FIELD ORIENTATION

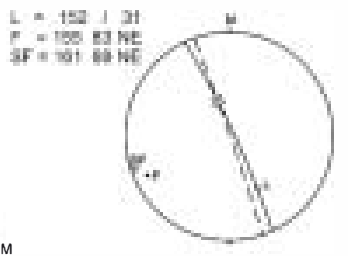

Rose of traverses $a=0.1094 \mathrm{~cm} \mathrm{~b}=0.1007 \mathrm{~cm}$

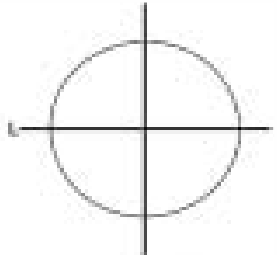

Characteristic shape
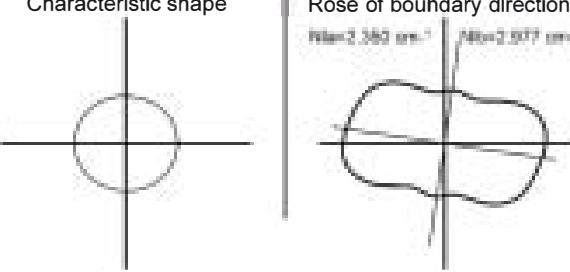

Rose of intercepts $a=31.7393 \mathrm{~cm} \quad b=25.0479 \mathrm{~cm}$ $R=1.267$

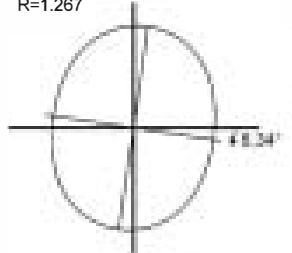

Rose of boundary directions

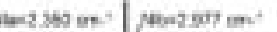

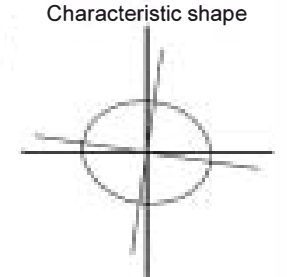

SPO of sample SO215

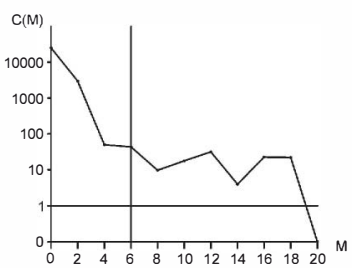

Rose of traverses $a=0.2426 \mathrm{~cm} \quad b=0.1915 \mathrm{~cm}$

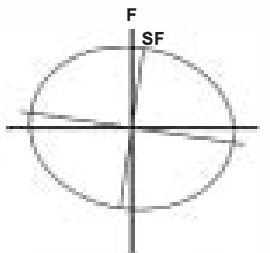

Characteristic shape

FIELD ORIENTATION

PLANE NORMAL TO FOLIATION $\mathrm{F}=12367 \mathrm{SE}$
$\mathrm{SF}=13559 \mathrm{SE}$
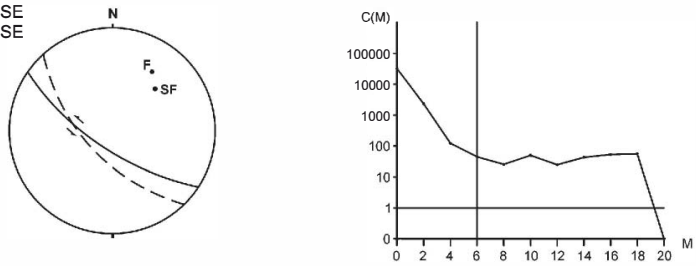

Rose of traverses $a=0.1014 \mathrm{~cm} \mathrm{~b}=0.1000 \mathrm{~cm}$

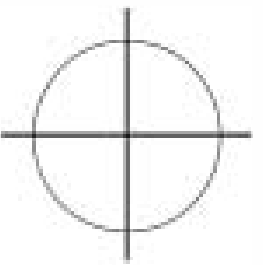

Characteristic shape

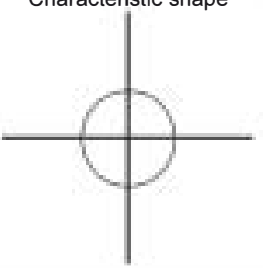

Rose of intercepts $a=39.4749 \mathrm{~cm} \mathrm{~b}=34.0506 \mathrm{~cm}$ $\mathrm{R}=1.159$

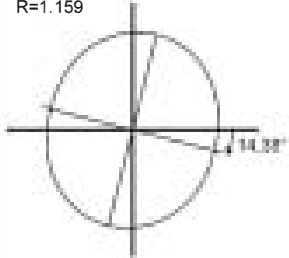

Rose of boundary directions Massacent| Nows resent

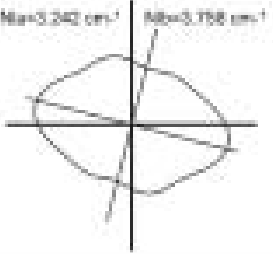

Rose of traverses $a=0.1738 \mathrm{~cm} \quad b=0.1499 \mathrm{~cm}$

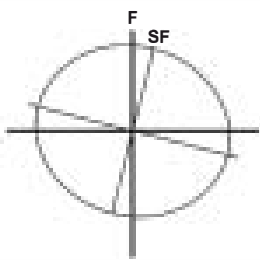

Characteristic shape

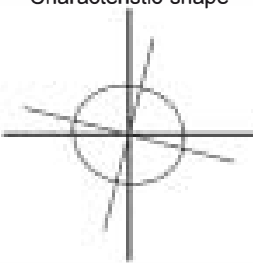

Fig. 3. SPO study of plagioclase grains performed by the intercept method on samples from the subvertical structural domain (SO226 and SO215), with the Fourier series truncation at $\mathrm{F}_{6}$. The results were obtained by using the freeware "Intercepts 2003". The rose of intercepts, the rose of traverses, the rose of boundary directions and characteristic shape are shown for a section within the foliation plane and a sectionnormal to foliation. The field orientation of the fabric elements (F: mesoscopic foliation, SF: shape foliation, and L: shape lineation) is shown in an equal-angle stereographic projection. 
1988; Ildefonse et al., 1992; Arbaret et al., 1996) yielding a fabric with moneclinic symmetry which can be used as a shear sense indicator.

During the magma coeling consecutively different mineral phases start to crystallize. If magma suffers any stress (tectøic stress, intemal stress caused by magmatic flow during emplacement, or filter pressing and porøus flow during crystallization, Paterson et al., 1998) the first phases to crystallize can easily be oriented forming a magmatic fabric. The first phases crystallizing are growing inte a liquid, consequently they show euhedral shapes controlle by their intemal crystallegraphic structure. This relates the SPO with the $\mathrm{CPO}$ in the first-crystallizing mineral phases. In the study presented below, a $\mathrm{CPO}$ has been determined for minerals formed during the crystallizing sequence in a plutonic røck, from the first formed and well oriented phases to the last-crystallized, usually pøikilitic and randomly oriented phases. The study was performed on the Santa lalla Igneøus Complex (SOIC), a well known, late-Variscan plutenic grøup located in the Olivenza-Monesterie antiform, a majør structure in the Ossa Mørena Zøne, SW Iberia (Fig. 1). The geømetry at depth of this plutenic complex and the orientation of their intemal fabrics is well constrained since the study by

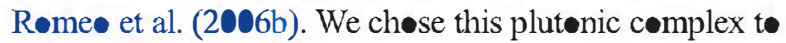
apply the EBSD technique because their emplacement mechanism was already established.

The SOIC is formed by twe main plutens: the larger Santa lalla steck and the Aguablanca stock. The Santa Olalla st॰ck (Eguiluz et al., 1989) cœmprises amphib॰lebiotite quartz-diorite in the northern area grading int a main tonalitic facies in the centre that passes to a small bødy of monzøgranite towards the søuthern limit. Towards the NW there is a mafic apophysis called Sultana, composed of hornblende-biotite tonalite and quartz-diorite. In the northern part of the complex is the Aguablanca støck, a mafic subcircular pluton (Røme• et al., in press). This is compesed of phløgøpite-rich gabbr-nørite and norite grading søuthwards inte diorite. On the north margin of the Aguablanca stock an $\mathrm{Ni}-\mathrm{Cu}-\mathrm{PGE}$ re depesit has been recently discovered (Lunar et al., 1997; Tornos et al., 1999, 2001; Ortega et al., 2004; Piña et al., 2006). Søme late-intruded granites complete the igneous intrusive sequence. The gechron logy of the complex is constrained since the $\mathrm{U}-\mathrm{Pb}$ results $\bullet$ btained by R॰me et al. (2006a) yielding ages within the interval of $340 \pm 3 \mathrm{Ma}$. These ages are similar to other plutons dated in the Olivenza-Mønesteri antiform (Dallmeyer et al., 1995; Bachiller et al., 1997; Casquet et al., 1998; Mønter et al., 2000), defining a main Variscan magmatic event, lasting from 353 to $329 \mathrm{Ma}$.
The SOIC is lecated in a wedge limited by twe main sinistral faults: the Cherneca Fault (Rome et al., 2007a) trending parallel to the general Variscan direction in this zone $\left(\mathrm{N} 120^{\circ}\right)$ with a reverse and sinistral kinematics, and the Zufre fault, a late-Variscan $\mathrm{N}^{\circ} 0^{\circ}$ sinistral strike-slip fault.

\section{Methodology}

\subsection{Shape preferred orientation (SPO) determined using the Intercept method}

Magmatic foliations are evident at the mesescale indicated by the parallelism of plagioclase crystals and can be used to establish the framework of each sample. The fabric will be analyzed in detail by determining the $\mathrm{CPO} \bullet$ f each mineral, but in order to completely constraint

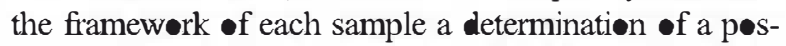
sible magmatic lineation is needed. Magmatic lineations in $\bullet$ ur samples are s- weak that they carmot be directly determined at the mesescale, s- we need a special technique to determine if they exist and how are they oriented.

The intercept methød (Launeau and R•bin, 1996) has been applied with the aim of constraining the magmatic shape fabric of plagieclase (the main oriented mineral in -ur samples). This technique allows us to detect the -rientation of magmatic lineations in our samples even if they are very weak, which has been very useful for interpreting the $\mathrm{CPO}$ study in the correct framework for each sample.

The intercept methed has been applied using the freeware "Intercepts 2003" created by Patrick Launeau and Pierre-Yves F. Røbin. The methød is based on counting the number of intercepted grain boundaries on a 2-dimensional image by a set $\bullet$ parallel scan lines aløng a number $\bullet$ directions. The resulting rose of intercept counts can be decomposed int a Fourier series, which can then be used to extract a rose of directions and a characteristic shape. For more details conceming this method see Launeau and Røbin (1996). The orientation of the shape fabric ellipse for each of the studied sections was $\bullet$ btained together with the intensity of the shape fabric which is determine by R (eccentricity of the shape fabric ellipse).

\subsection{Crystallographic preferred orientation (CP ) determined by Electron Back-Scatter Diffraction (EBSD)}

In a scanning electrøn micrøscøpe (SEM) an electrøn beam creates an omni-directional source of scattered electrons within a specimen. Diffraction $\bullet$ these electrøns will $\bullet$ ccur simultane usly on all lattice planes in the sample and the backscattered electrons, which escape 
FOLIATION PLANE
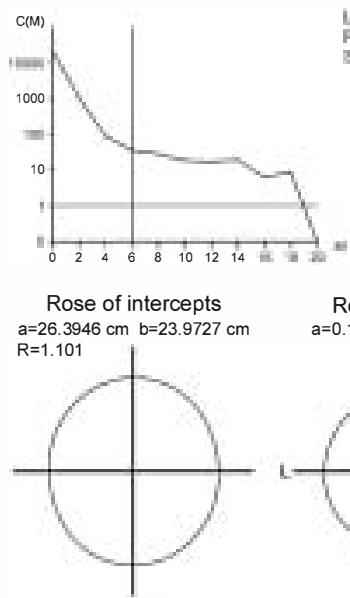

Rose of boundary directions \begin{tabular}{l|l}
$\mathrm{Nla}=3.123 \mathrm{~cm}^{-1}$ & $\mathrm{Nlb}=3.438 \mathrm{~cm}^{-1}$
\end{tabular}

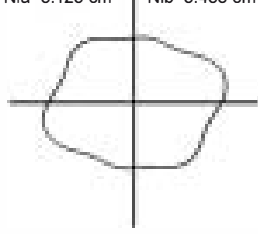

FIELD ORIENTATION

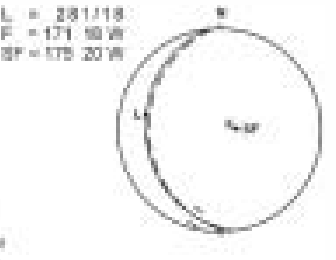

PLANE NORMAL TO FOLIATION

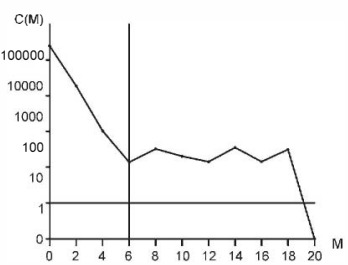

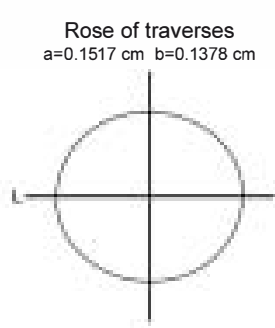

Characteristic shape
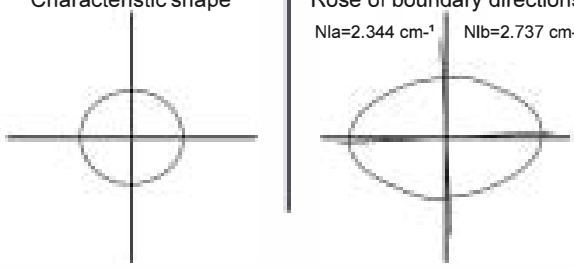

Rose of traverses

Rose of intercepts $a=30.0676 \mathrm{~cm} \quad b=25.7570 \mathrm{~cm}$ $\mathrm{R}=1.16$
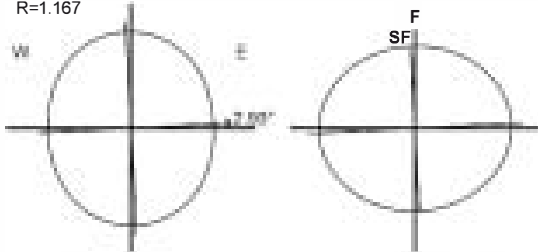

Characteristic shape

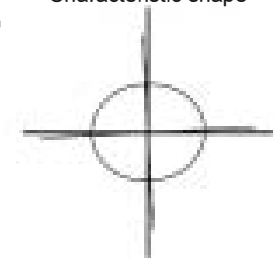

\section{SPO of sample SO224}

FOLIATION PLANE
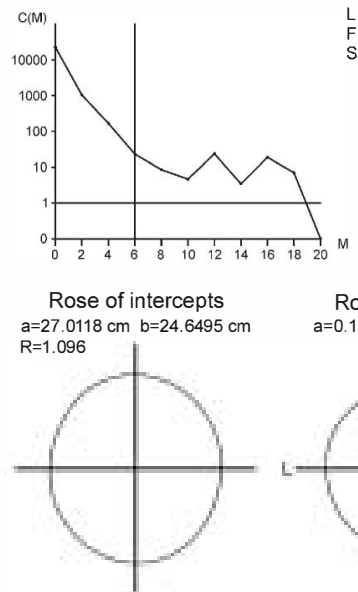

Rose of boundary directions

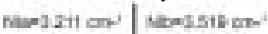

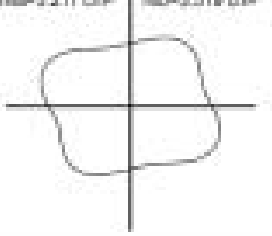

FIELD ORIENTATION

$\mathrm{L}=244 / 14$
$\mathrm{~F}=2824 \mathrm{NW}$

$\mathrm{SF}=2524 \mathrm{NW}$

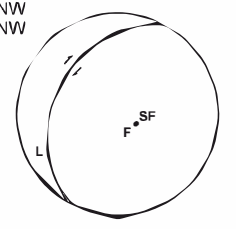

PLANE NORMAL TO FOLIATION

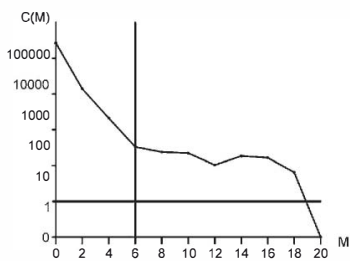

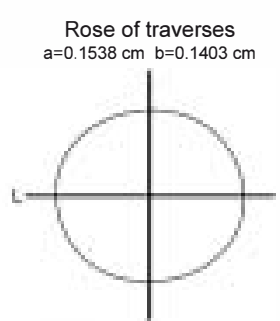

Characteristic shape

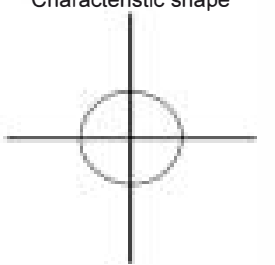

Rose of intercepts $a=31.4412 \mathrm{~cm} \mathrm{~b}=28.2437 \mathrm{~cm}$ $R=1.113$

is

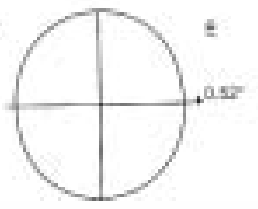

Rose of boundary directions $\mathrm{Nla}=2.612 \mathrm{~cm}^{-1} \quad \mathrm{Nlb}=2.908 \mathrm{~cm}^{-1}$

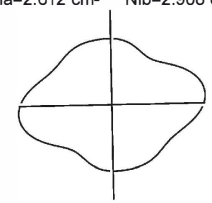

Rose of traverses $a=0.2118 \mathrm{~cm} \mathrm{~b}=0.1902 \mathrm{~cm}$

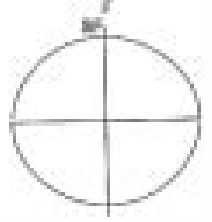

Characteristic shape

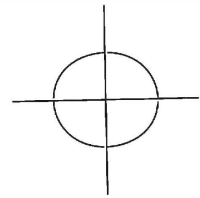

Fig. 4. SPO study of plagioclase grains performed by the intercept method on samples from the subhorizontal structural domain (SO222 and SO224), with the Fourier series truncation at $\mathrm{F}_{6}$. The results were obtained by using the freeware "Intercepts 2003 ". The rose of intercepts, the rose of traverses, the rose of boundary directions and characteristic shape are shown for a section within the foliation plane and a sectionnormal to foliation. The field orientation of the fabric elements (F: mesoscopic foliation, SF: shape foliation, and L: shape lineation) is shown in an equal-angle stereographic projection. 
from the specimen, will form a diffraction pattern that can be imaged on a phosphor screen. This is the basis of Electron Back-Scatter Diffraction (EBSD) (Priør et al., 1999). Similar diffraction effects cause individual grains -f different orientations to give different total backscattere electrons. EBSD enables measurement of the crystallegraphic •rientation of individual rock-forming minerals as small as $1 \mu \mathrm{m}$.

The EBSD analyses were ebtained using an HKL Channel5 EBSD system on a Philips XL30CP SEM

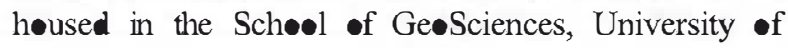
Edinburgh. While EBSD analyses can be collected automatically, performing a grid of measurements with a regular spacing, this automatic mapping method was rejected due to the high number of phases to index. The analyses were cøllected manually, $\bullet$ e by $\bullet$ e, a prøcedure that allows to check the correct indexing •f each electron back-scatter pattern for each previously recognized phase. Manual mapping completely covered the thin section surface in order to take the all the grains available in each sample. The number of analysis performed for each phase and sample, $N$, is reported in each diagram (Figs. 5-8).

\section{Igneous structure}

An explanation of the orientation of the magmatic foliations at the mesoscale is require before we present the results of eur fabric study in order to understand the structural lecation of each analyzed sample.

The SOIC was deformed during the magmatic phase, and no evidence $\bullet$ important sub-sølidus strain has been found. Only quartz shøws a weak sub-sølidus deformation characterize by undulese extinction and subgrains, while plagiøclase, biøtite, and hornblende remain undeformed. The tonalite, quartzdiorite and gabbronorite show preferred orientations of plagieclase (1-4 mm long) forming magmatic foliations favoured by the planar habit of this mineral. These mesescopic magmatic foliations were mapped, (Fig. 2) revealing a consistent •rientation pattern in which tw• different structural domains can be distinguished: an NE area trending parallel to the long axis of the stock, where the foliations show dominantly an NW-SE trend and vertical or high dip angle foliations, and the SW area where foliations are dominantly of low dip angle or hørizental (see stere plots shøwn in Fig. 2).

The vertical $\mathrm{N} 140^{\circ}$ striking structural domain of the $\mathrm{NE}$ margin is concordant with the structural trajectories

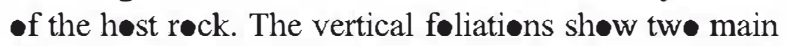
directions: bands (100-200 m wide) with an N130 strike and dipping $90^{\circ}$ to $70^{\circ}$ to the south and, between these bands, foliations quite $\bullet$ blique with an $\mathrm{N} 155^{\circ}$ trend and vertical dips. In the foliation trajectory map this pattern $\bullet$ utlines rhømbøidal shapes ( $\mathrm{A}$ in Fig. 2) that were interpreted as kilømetre-scale $\mathrm{S}-\mathrm{C}$ structures (R॰me• et al., 2006b).

The sub-herizental structural demain in the SW shows that magmatic foliations are dominantly discordant with respect to the intrusive contact, but the host rock structure is dominantly parallel to the pluten margins. The transition between both domains is mainly characterized by narrow bands with vertical foliations striking $\mathrm{N} 155^{\circ}$ that appear to cut the surrounding horizontal fabrics. With respect to the relationships with the main faults it can be deduced that the Zufre fault has a clear post-intrusive character as it cuts all the foliations in the tonalite, unlike the Cherneca fault which runs parallel to the subvertical domain of the SOIC.

An extensive structural analysis combined with gravity modelling has been recently performed (Rome et al., $2006 \mathrm{~b})$ giving an interpretation of the emplacement mechanism and tectonic evolution during cœeling, that can be summarised as follows. First, during the syntectonic sinistral movement of the Cherneca fault the ascent -f magma took place favoured by the generation of vertical pull-apart inter-connected gaps along this structure. When magmas reach its final level of emplacement a hørizental sheet-like intrusion started to prøpagate towards the SW generating the subhorizental structural domain parallel to the upper and lower magma host rock contacts. Stoping alse played an impertant role alløwing a moderate ascent of the magma in the last stages $\bullet$ emplacement. Continuous motion along the Cherneca fault produced the sinistral shear deformation in a magmatic state of the NE pørtion of the Santa Olalla Igneøus Complex, which generated a superimpesed vertical fabric with sinistral kilometric-scale $\mathrm{S}-\mathrm{C}$ magmatic structures. Finally, after complete crystallization of the magma at this

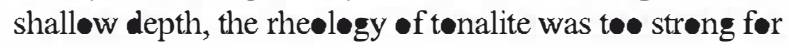
deformation to proceed under sub-sølidus conditions. As a consequence, the wide shear deformation zone allowed by melt rheølogy, was again restricted the initial fault trace. Some time later, the Zufre fault cut across the Santa Olalla Igneous Complex, displacing its SE portion below the present erosion level.

\section{Fabric study}

The Santa Olalla tonalite was sampled in order to study the magmatic fabric in detail. Føur samples were analyzed by the Intercept Methød and EBSD: 2 frøm the subhorizental domain (SO222 and SO224) and 2 from the subvertical domain (SO215 and SO226), the lecatiøns are sh॰wn in Fig. 2. 

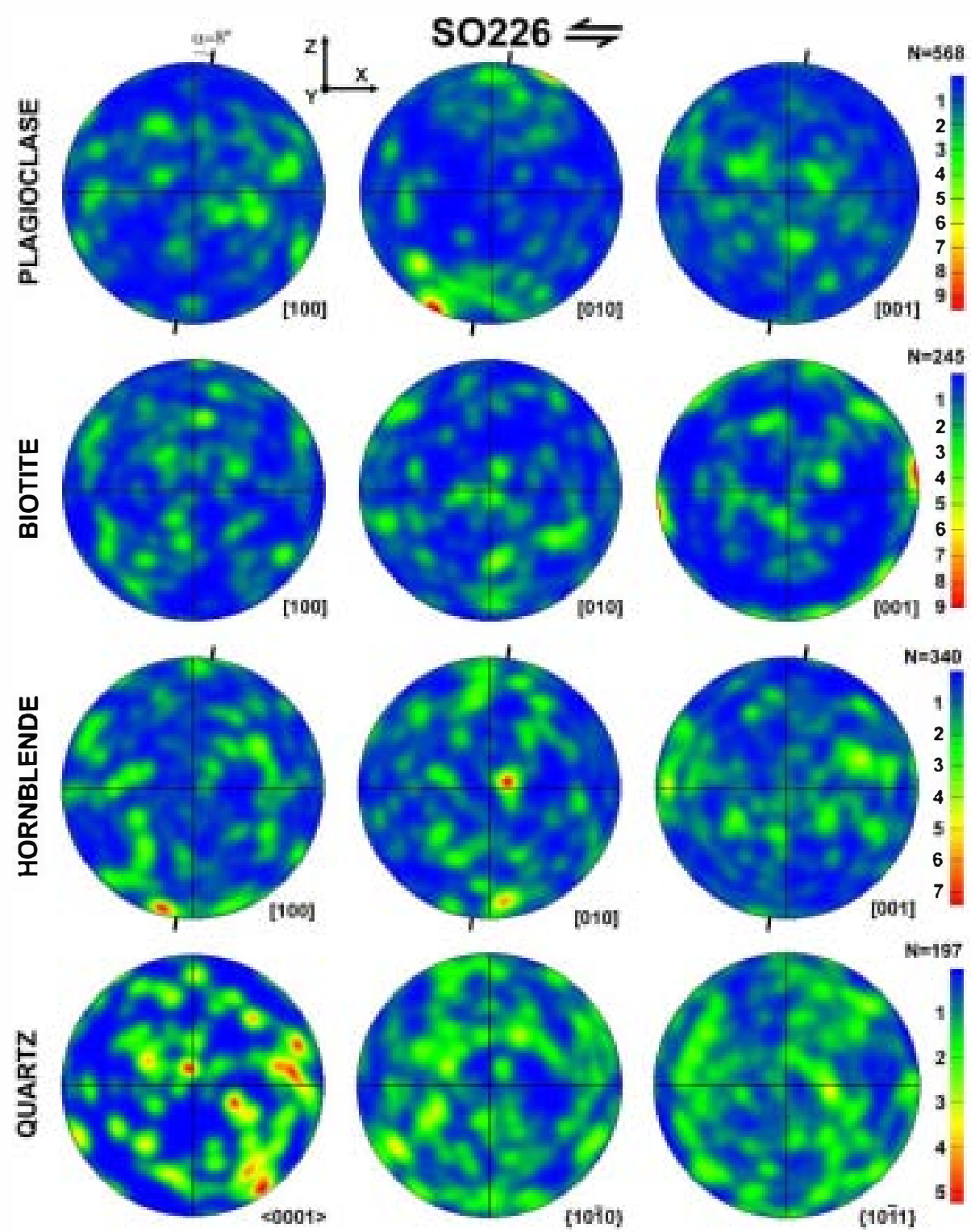

Fig. 5. Lower hemisphere equal-area projections of the CPOs of plagioclase, biotite, homblende and quartz for the samples SO226 (subvertical domain) obtaine by EBSD. The plane XY corresponds to the measured mesoscopic foliation and X to the lineation obtained in the SPO study of plagioclase. The $\alpha$ angle of plagioclase is indicated. $N$ is the number of EBS measurements. The units of the scale bars are multiples of random distribution.

\subsection{Shape preferred orientation}

For each sample two images were analyzed by the intercept method. One image corresponding to a section normal to foliation and the other within the foliation plane. The image perpendicular to foliation allows us to infer the intensity of the planar fabric of each sample, while the image parallel to foliation indicates the direction and intensity of the magmatic lineation if present.

The mineral used for the SPO study was plagioclase because it is the main fabric forming phase in all the samples. The images were •btained by scanning thin sections, these images were then processed in order to identify with a unique coløur for the plagieclase. Finally, the ebtained images were analyzed by the freeware "Intercepts 2003" with the Fourier series truncation at $\mathrm{F}_{6}$, -btaining the following results (Figs. 3, 4).

\subsubsection{Subvertical domain (SO226, SO215)}

The SPO analysis of sample SO226 is sh॰wn in Fig. 3. It has revealed a magmatic lineation with a subhorizontal $\bullet$ rientation $\left(31^{\circ} \bullet\right.$ f immersion). The SPO •btained within 


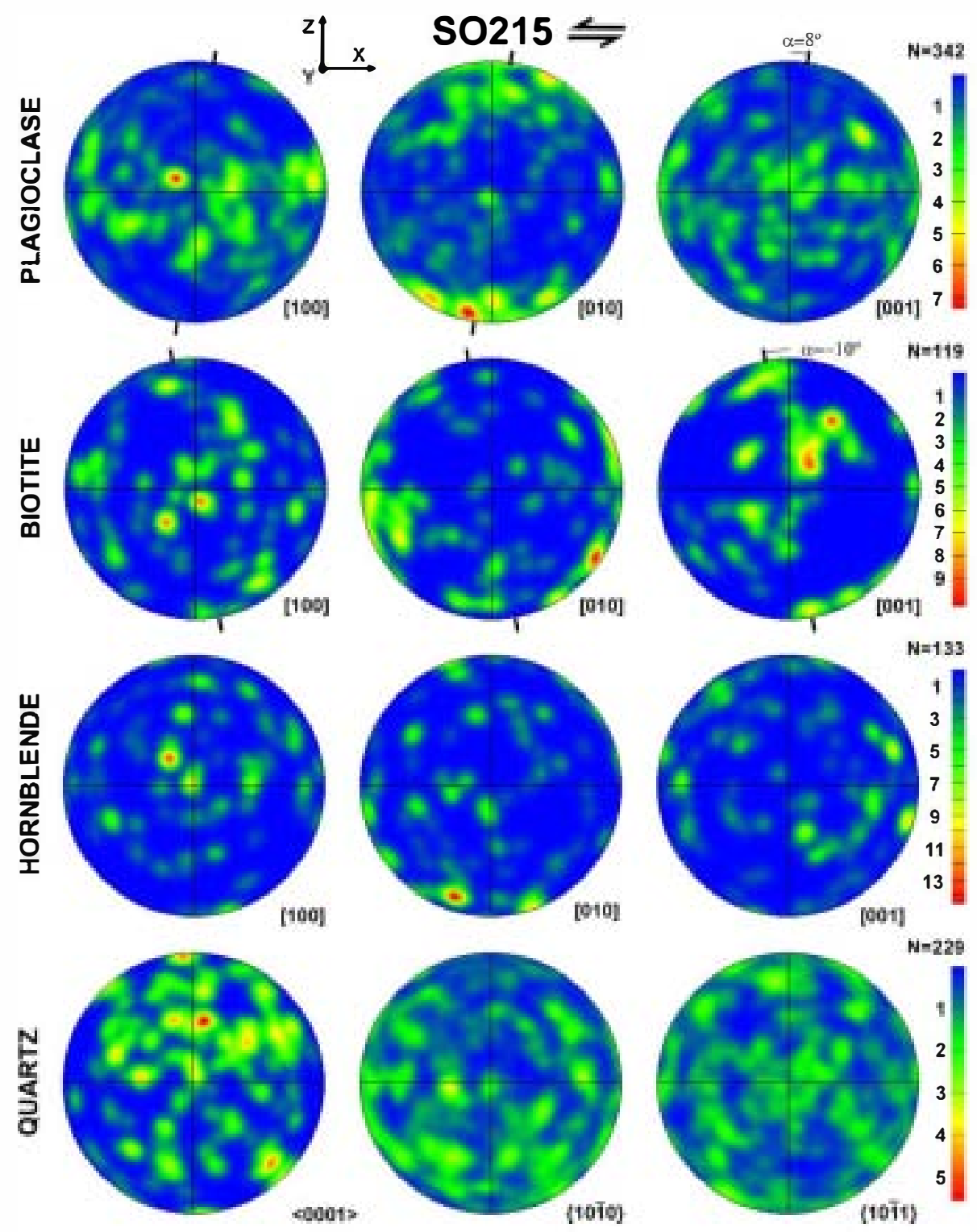

Fig. 6. Lower hemisphere equal-area projections of the CPOs of plagioclase, biotite, homblende and quartz for the samples SO215 (subvertical domain) obtaine by EBSD. The plane XY corresponds to the measured mesoscopic foliation and X to the horizontal line inside the foliation. The $\alpha$ angle of plagioclase and biotite are indicated. $N$ is the number of EBS measurements. The units of the scale bars are multiples of random distribution.

the foliation plane presents $R=1.086$ ( $R$ is the eccentricity -f the shape fabric ellipse), which indicates that the lineation is weak. The fabric is mainly planar as indicates the SPO results for the plane normal to foliation $(R=1.267)$, but the orientation of the foliation $\bullet$ btained by the Intercept method (shape foliation) is •blique $\left(8.34^{\circ}\right)$ in respect to the measured mesescopic foliation. The obtained elements of the fabric L (lineation), F (pøle to mesøscopic foliation), SF (pøle to the shape foliation) are als• represented in ge graphic cœerdinates in Fig. 3.
The results of the SPO study performed for sample SO215 are quite different (Fig. 3). The fabric in this case is planar and there is no evidence of lineation in the shape -rientation of plagioclase $(R \approx 1$ in the study within the mesescopic foliation). The study of the plane normal to foliation indicates a planar fabric less intense $(R=1.159)$ than the previous sample (SO226). Again the foliation -bserved by the Intercept Method (shape foliation, SF) is not exactly parallel to the mesescopic foliation $\bullet$ bserved in the sample (F), forming both planes $14.38^{\circ}$. 

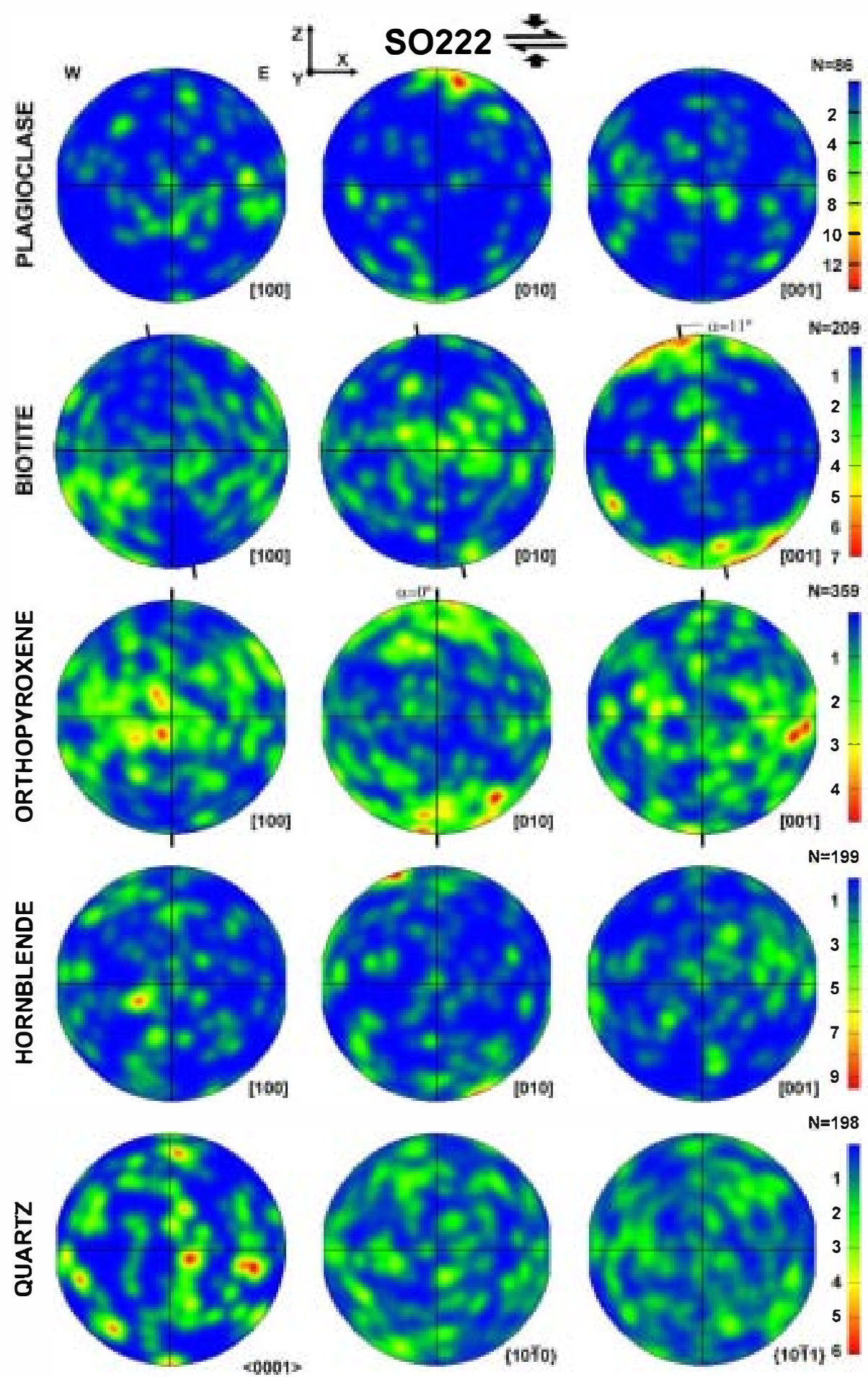

Fig. 7. Lower hemisphere equal-area projections of the CPOs of plagioclase, biotite, orthopyroxene, homblende and quartz for the samples SO222 (subhorizontal domain) obtaine by EBSD. The plane XY corresponds to the measured mesoscopic foliation and X to the lineation obtained in the SPO study of plagioclase. The $\alpha$ angle of biotite is indicated. $N$ is the number of EBSD measurements. Note that the number of measurements on plagioclase is small compared with the other samples, we to the more mafic composition of SO222. The units of the scale bars are multiples of random distribution. 

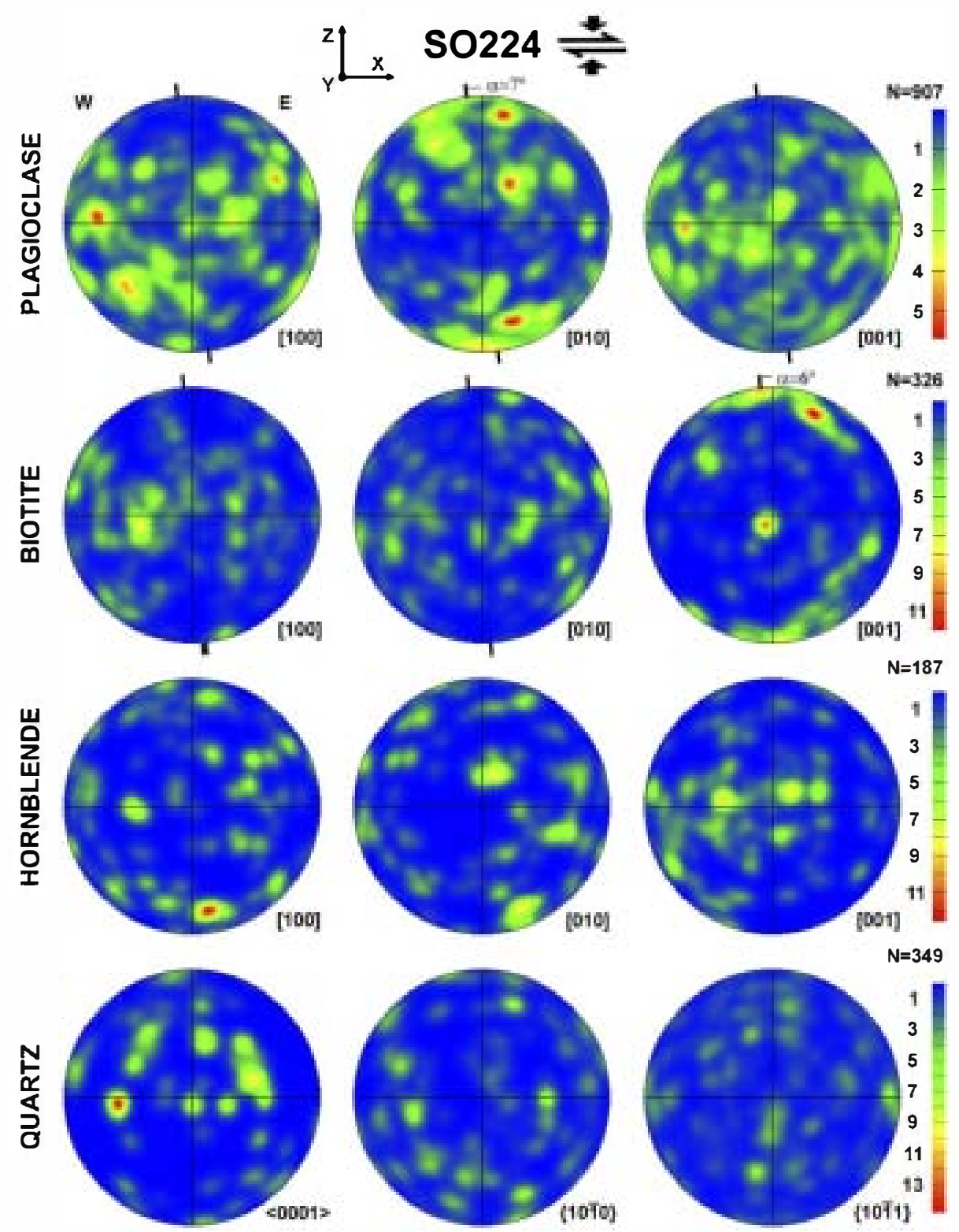

Fig. 8. Lower hemisphere equal-area projections of the CPOs of plagioclase, biotite, homblende and quartz for the samples SO224 (subhorizontal domain) obtained by EBSD. The plane XY corresponds to the measured mesoscopic foliation and X to the lineation obtained in the SPO study of plagioclase. The $\alpha$ angle of plagioclase and biotite are indicated. Nis the number of EBSD measurements. The units of the scale bars are multiples of random distribution.

\subsubsection{Subhorizontal domain (SO222, SO224)}

The SPO study of the samples frøm the subherizental domain has revealed, in both cases, magmatic lineations trending to the W (SO222, Fig. 4) and WSW (SO224, Fig. 4). The shape foliations evidenced by the Intercept Method in these samples are, as those samples from the subvertical domain, $\bullet$ blique in respect to the mesøscopic foliations, but forming smaller angles in this case $\left(2.93^{\circ}\right.$ in $\mathrm{S} \mathbf{2 2 2}$ and $\mathbf{0 . 5 2 ^ { \circ }}$ in SO224). The intensity of lineations is very weak $(R=1.101$ for SO222 and
$R=1.096$ for SO224) while the intensity of foliations is higher $(R=1.167$ for SO222 and $R=1.113$ for SO224). The orientation in geographic coordinates for all the fabric elements can be seen in Fig. 4.

\subsection{Magmatic CPOs}

The SPO analysis has identified that weak magmatic lineations were present in three of our samples. The orientation of the framework is well established for 
these samples ( $\mathrm{X}$ is parallel to the shape lineation, $\mathrm{Z}$ is assumed to be located in the pole of the observed mesescopic foliation and $Y$ is perpendicularly $\bullet$ riented).

The CPOs of the main mineral phases (labradorite, biotite, orthøyroxene if present, hornblende and quartz) were analyzed for each sample.

The crystallization sequence in the Santa Olalla tonalite indicated by igneous textures is: firstly plagiøclase with the most euhedral morphølogies, secondly

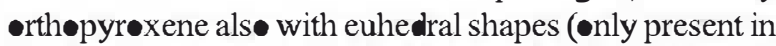
sample SO222), thirdly biotite als• with euhedral shapes, fourthly hornblende with anhedral shapes sømetimes showing poikilitic textures and finally quartz which

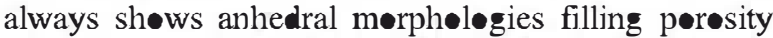
with poikilitic textures.

The results of the CPO study are presented in Figs. 5-8, corresp^nding to SO226, SO215, SO222 and SO224, respectively. The results are presented on stere plots, with the pøle to the measured mesescopic foliation (Z) oriented $\mathrm{N}-\mathrm{S}$ in the diagram, and the shape lineation $(\mathrm{X})$ in the $\mathrm{E}-\mathrm{W}$ direction of the diagram. The results for SO215, the sample of the subvertical structural domain that does not show shape lineation has been represented with the horizental line within the foliation located in the E-W direction of the diagram.

\subsubsection{Subvertical domain (SO226, SO215)}

Plagieclase fabrics in the samples belonging to the subvertical domain are characterized a vertical magmatic foliation defined by the 010 p les (the more developed face of plagioclase growing int a liquid) which is coherent with the field •bservations. In detail, the 010 plagieclase pøles show an asymmetric •rientation with respect to $Z$ (Figs. 5 and 6) implying a degree -f crystal imbrication or tiling (Blumenfeld, 1983; Blumenfeld and Bouchez, 1988; Ildefonse et al., 1992; Arbaret et al., 1996). This imbrication can be interpreted as a sinistral simple shear strain with a horizontal direction during the generation of the vertical magmatic føliation. The 001 and 100 pøles of plagiøclase define a diffuse girdle perpendicular to the 010 maximum featuring ne clear crystallographic lineation in the plagieclase fabric, from which it can be deduced that the shape lineation detected in sample SO226 is formed by axes 001 and 100. The biotite subfabric is more random than that of the plagieclase. While the plagieclase shows coarse euhedral grains and a clearly planar igne us fabric, the biotite with a smaller size and more isømetric shapes show an intriguing and complex CPO. The 001 pøles of biotite that define its planar habit are distributed with a girdle within XZ in SO226 (Fig. 5) completed with a concentration around Y. The biotite subfabric $\bullet 20215$ is less clearly defined, althøugh it is similar to SO226. The complex pattern of 001 p•les together with the similar crystalløgraphic develøpment -f 010 and 100 planes in biotites yield a near random -rientation of the 010 and 100 p॰les. The CPOs of hornblende differs between the tw• samples SO215 and SO226. SO215 is a tonalite with a minor amount of hornblende and yields a random orientation for this mineral, indicating a late crystallization with a pøikilitic texture. In contrast the hornblende in SO226 (a hornblende rich quartzdiorite) has been weakly oriented during the magmatic state, giving a søft girdle in the XY foliation plane for the long axis of hornblende prisms (001), like in the case of the plagioclase the girdle of the 001 axes $\bullet$ h hornblende is slightly $\bullet b l i q u e$ to the foliation plane giving the same sinistral shear sense. The last mineral to crystallize was quartz, filling the gaps between -ther phases with poikilitic textures. Thus, both samples show a random $\mathrm{CPO}$ of the $c$-axes of quartz.

\subsubsection{Subhorizontal domain (SO222, SO224)}

These samples feature similar plagiøclase CPOs to the samples from the subvertical domain. The 010 plagioclase pøles clearly define the igneous foliation measured in the field. In this case, while SO222 presents an almost orthorh mbic symmetry for the CPO of plagieclase (Fig. 7), SO224 shows a degree of tiling (Fig. 8) indicating

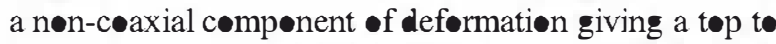
the E shear sense. In both samples the 001 and 100 plagioclase pøles, are distributed with random orientations in girdles perpendicular to the $\mathbf{0 1 0}$ maximum. Consequently the contribution of 001 and 100 axes to the magmatic lineation is similar.

In contrast to the results $\bullet$ btained for the subvertical domain, the biotite CPOs of the samples from the subhorizental domain are more concordant with the fabrics $\bullet$ plagieclase. The 001 biotite poles show the same -rientation as the 010 plagioclase pøles in sample SO224 (Fig. 8), and a subparallel orientation in SO222 (Fig. 7). This indicates that the preferred orientation of biotite plates als contributes to the magmatic foliation observed in the field.

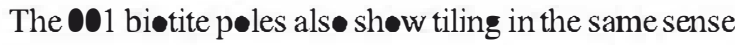
that was $\bullet$ bserved for the $\mathbf{0 1 0}$ plagieclase p•les, in SO224 (Fig. 8); and a similar tiling in SO222, contrasting with the orthorhombic fabric of plagieclase in this sample. The tiling of biotite in both samples gives a top to the $\mathrm{E}$ shear sense. The 010 and 100 biotite pøles define girdles perpendicular to the $\mathbf{0 0 1}$ maximum. Sample SO222 (Fig. 7) indicates that there is a difference in the -rientation of 010 and 100 axes within the girdle, with the 100 axes being better oriented the shape lineation. 


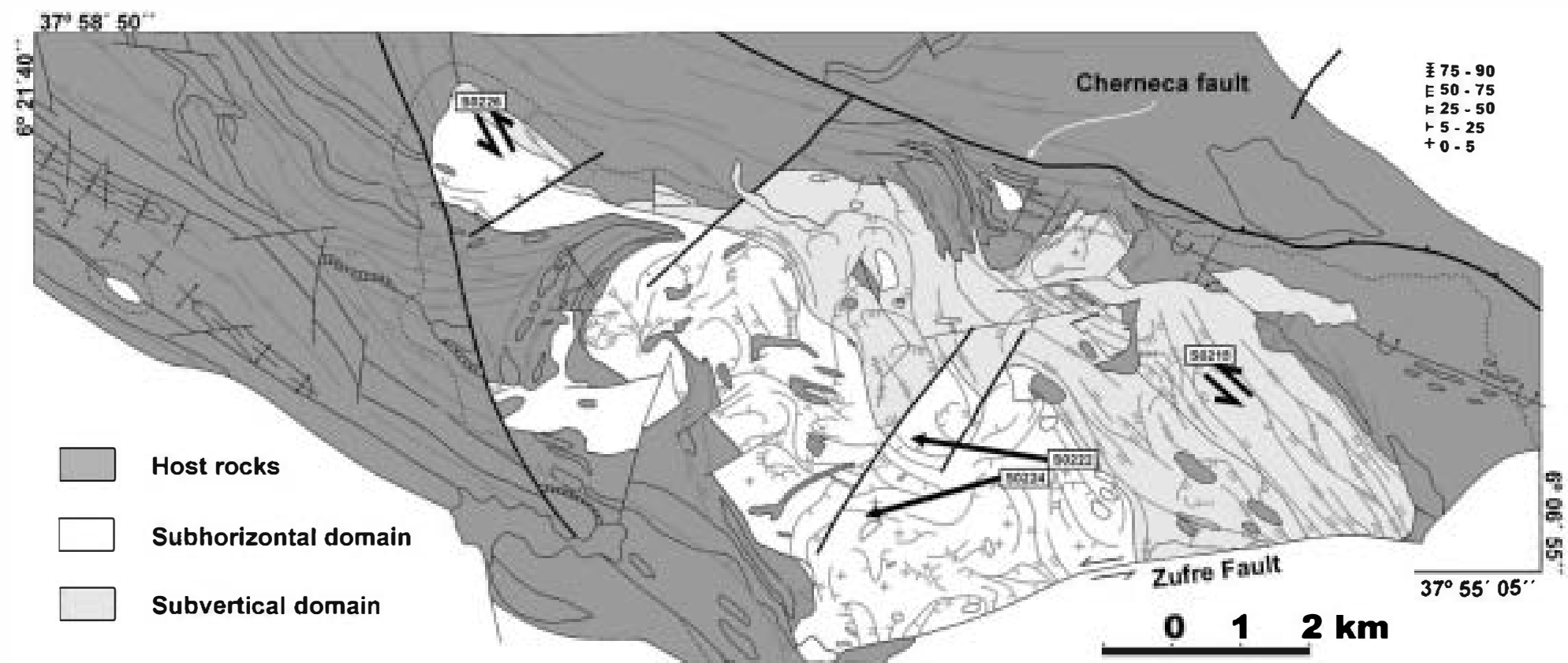

Fig. 9. Shear sense (subvertical domain) and the directions of magma flow (subhorizon domain) obtained by the SPO and CPO study, represented on the foliation rajectory map. 

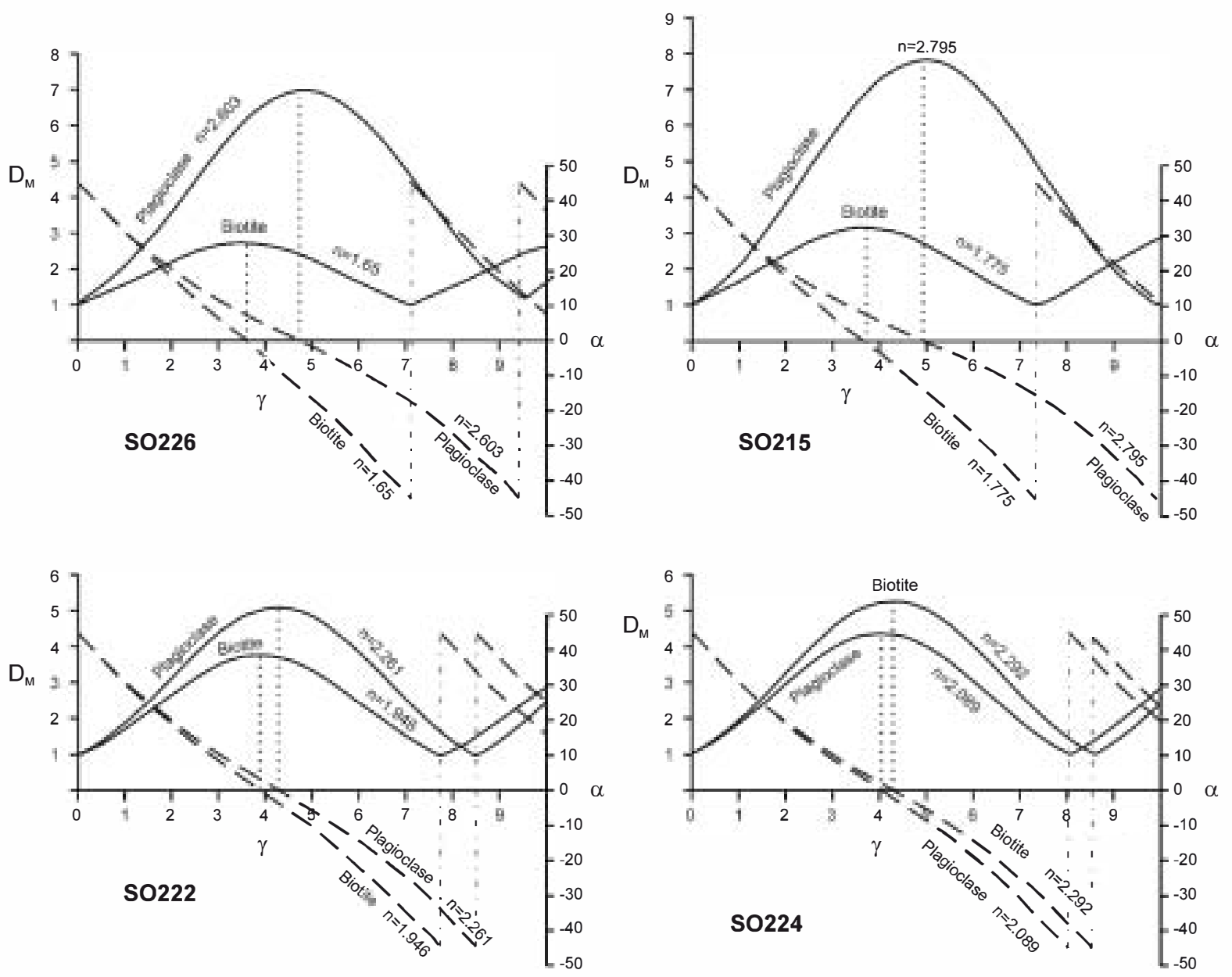

Fig. 10. Numerical modelling of the fabric evolution of plagioclase and biotite for all the samples.

SO222 is the only sample that presents a significant amount of orthopyroxene. This phase starts to crystallize in the first places, when a large amount of liquid is still present and consequently the formation of a magmatic fabric by this mineral is possible. The CPO of orthopyroxene in SO222 is very strong. It is characterized by an orthorhombic symmetry with the 010 poles aligned on $\mathrm{Z}$, defining the mesoscopic magmatic foliation. The 001 and 100 axes are distributed in a girdle within the foliation, with stronger maxima in the shape lineation (X) for the 001 axes (which correspond to the elongation of prisms) and in the $\mathrm{Y}$ direction for the 100 poles.

The long axes of the hornblende prisms (001) are distributed with random orientations although the highest density can be observed in a wide girdle containing the $\mathrm{XY}$ foliation plane (especially clear for SO222, Fig. 7). The random CPOs of quartz (Figs. 7 and 8) reflect, as in the samples from the subvertical domain, that this mineral is the last one to crystallize.

\section{Discussion}

The SPO study of plagioclase grains has served to reveal the presence of weak magmatic lineations, but also has served to evaluate the intensity of the planar fabric. The foliation measured at the mesoscale does not completely fit with the orientation of the foliation detected by the Intercept Method. This can be interpreted as being caused by a tiling of the plagioclase grains oriented during a non-coaxial deformation. The mesoscale foliation can be assumed as the general flow plain, but the detailed shape study reveals an oblique orientation of the shape foliation caused by a tiling of the crystals, indicative of a shear sense for each sample. The obtained shear sense for each sample is indicated in the stereo plot of the fabric 
elements in ge graphic cœerdinates sh॰wn in Figs. 3-4. This interpretation of the monoclinic symmetry of the SPO is supported by the fact that the results are completely coherent with the interpretation of the emplacement mechanisms and tectonic evolution of the SOIC prøpesed by Røme et al. (2006b). The samples from the subhorizontal domain show a top to the W shear sense. Taking inte account that the SOIC is only incipiently eroded can be considered that the non-coaxial deformation during the generation of the subhorizontal domain was caused by a drag against the upper boundary -f this tabular intrusion. This interpretation allows us to infer that the plagieclase tiling in both samples (SO222 and SO224, top to the E) indicate a westwards magma entering. These inferred flow directions (parallel to the shape lineation) are indicated in Fig. 9 and are coherent with the entrance $\bullet$ magma from the røots $\bullet$ btained by gravity modelling (R॰me et al., 2006b). The samples

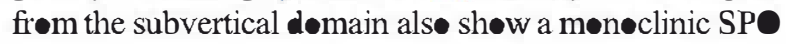
caused by plagieclase tiling indicating a sinistral noncoaxial deformation in magmatic state (Fig. 3). These

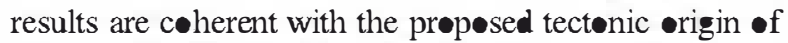
the subvertical domain as caused by the sinistral deformation in the magmatic state. This was promoted by the Cherneca fault strain field, an interpretation initially based on the S-C structures shown in the foliation trajectory map (Fig. 2) and the presence of vertical corriders cress-cutting previøus subhørizontal foliations (Røme et al., 2006b). The shear sense •btained by the mon clinic symmetry of the subvertical domain samples (sinistral) is alse shown in Fig. 9.

The relationship between the fabrics of each mineral phase btaine by EBSD is cømplex. Plagieclase, bi tite and orthopyroxene (when present) are the main fabricforming minerals, and hornblende plays a role during fabric generation only in the more mafic samples (quartzdiorites), while quartz is always the last main phase to crystallize and consequently shows random -rientatiens. The subherizontal domain displays a parallelism between the preferred orientation of plagieclase and biotite, contrasting with the subvertical domain which shows very different $\mathrm{CPO}$ s for these phases.

The subvertical domain features a foliation defined by 010 plagieclase pøles in Figs. 5 and 6 with a degree of tiling consistent with a genesis by sinistral shearing, this is a new determination of the same tiling $\bullet$ bserved in the SPO study (Fig. 3). Plagioclase as the main flat-shaped mineral underwent rotation under a nøn-cøaxial strain until the interactions between grains stabilized the -bserved imbricated fabric. Nevertheless the biotite, with its smaller size, shows a more complex CPO (Figs. 5 and 6). These biotite CPOs are characterized by a girdle of 001 pøles in the $\mathrm{XZ}$ plane and a concentration around the $Y$ direction. Small biotite grains can rotate under non-coaxial deformation between the main plagieclase crystals giving the observed XZ girdle of 001 pøles. 2D analogue simulations of magmatic type simple shear with twø sizes $\bullet$ grains shøws that the larger phase is well -riented with a tiling consistent with the shear sense while the smaller phase is near randomly oriented in the $\mathrm{XZ}$ plane (See Fig. 9 of Ildefonse et al., 1992). In natural samples it has been demonstrated that size is related the degree of fabric anisotropy of each phase, for example Arbaret et al. (2000) describe a more pronøunced SPO anisotropy for K-feldspars phenocrysts than smaller biotite crystals in the same granite.

In the samples from the subvertical domain the concentration of 001 biotite pøles around $Y$ can be interpreted as a relict fabric. These biotites are horizontally dispesed and are subparallel to the plagieclase and biotite fabrics of the adjacent subhorizental domain. A partial reorientation of this horizontal fabric under simple shear conditions during the magmatic stage could explain the complex bi tite $\mathrm{CP}$ patterns $\bullet$ bserved. During sinistral shearing, the initially horizental biotite plates with 001 p॰les arøund $Y$, start to røate folløwing a spiral path until reaching the $X Z$ plane. Similar spiral paths were obtained by Launeau (2004) by modelling the evelution -f previous fabrics reworked under simple shear. This sinistral shearing could completely rework the plagioclase fabric due to its bigger size, which implies more interactions allowing the stabilization of an imbricated fabric, whereas the reorientation of a smaller phase as biotite was only partial before final crystallization.

The foliations of the subhorizental domain are alsø defined by the 010 plagieclase pøles. In SO224 the plagieclase displays a degree of tiling indicating a simple shear component of strain (Fig. 8). The small amount of plagieclase in SO222, caused by the presence -f orthopyroxene, gives a less defined CPO for plagioclase $(\mathrm{V}=86)$ (Fig. 7$)$ and consequently we are not convinced if there is a degree of tiling in this CPO. However, the small tiling described by the SPO study is coherent with the tiling observed in the CPO ०f SO224, all indicating a down to the W shear sense. Considering this, the most probable origin of the igneous foliation during the entrance of magma int the tabular intrusion creating the subherizental domain was magmatic flew, which is consistent with a non-coaxial flow caused by drag towards the upper contact with the hest røcks. In contrast to the biotite CPOs of the subvertical domain, the biotites in the subherizental demain display similar CPOs to plagioclase, indicating that free rotation of smaller phases was not allowed during shearing in this 
domain, which could indicate a significant flattening towards the upper horizental boundary during emplacement. Hence, the most likely interpretation for the origin - the subhorizontal fabrics is a combination of simple shear with pure shear. This is not unlikely if we consider that during the swelling of any pluton (whether this -ccurs passively or n॰t) magma has t• enter at the same time that the cavity is generated, which necessarily causes a dragging of magma towards the boundaries accompanied by flattening parallel to the boundaries caused by the confining pressure.

\section{Numerical modelling}

A 2D numerical modelling based on the formulation of Jeffery (1922) for rotation of rigid ellipsøids fleating int a melt under simple shear conditions has been applied to the particular cases of our samples. The theory was generalized by Willis (1977) for arbitrary shaped particles. The solution for 2D simple shear was analyzed by Femandez et al. (1983) and supported with analogue experiments.

The curves describing the evolution of the fabric in terms of $D_{\mathrm{M}}$ (intensity of the strain ellipse) and $\alpha$ (angle $\bullet$ the $\mathrm{X}$ axis of the strain ellipse and the shear plane) with respect to $\gamma$ (shear strain) for each particular sample have been obtaine by measuring the value of $n$ (aspect ratio) for plagieclase and biotite on the XZ plane. The parameter $n$ has been $\bullet$ btained from the average aspect rati $\bullet$ all the grains present in each sample. For details of how to generate the curves see Femandez et al. (1983). We have applied this model to our samples, and this has yielded a very useful technique for evaluating how some complex textures can be formed (for instance it can explain the -pposite sense of tiling of different phases in the same sample).

The models describe the periodical evolution of the fabric suffering a simple shear flow. It starts with a random initial orientation of the grains $\left(D_{\mathrm{M}}=1\right)$, the intensity of the fabric increases with a progressive reduction $\bullet$ the positive values of $\alpha$ until the fabric gets parallel to the flow plane $(\alpha=0)$ and the intensity is maximum $\left(D_{M}=\max \right)$. Later, $\alpha$ reaches negative values indicating a mon $\bullet$ linic symmetry $\bullet$ pposite to the shear sense, the fabric intensity decreases and becomes random, starting a new cycle again. The periodicity of the fabric evolution cycle only depends on the aspect rativ $(n)$ of the grains. As plagieclase and biotite have very different aspect ratios, there is always a lag of the fabric evelution cycle between both minerals.

The models calculated for the samples of the subvertical domain are shewn in Fig. 10. The angles between the shear plane (XY) and the 010 plagieclase planes and 001 biøtite planes can be $\bullet$ btained from the CPOs ( $\alpha$ angles). For SO226 the $\alpha$ angle of plagioclase is $8^{\circ}$ indicating a $\gamma=3.5$ (Fig. 10), while the complex biotite CPO does not show a preferred $\alpha$ angle. For SO215 (Fig. 6), opposite $\alpha$ angles for plagieclase $\left(\alpha=8^{\circ}\right)$ and biotite $\left(\alpha=-10^{\circ}\right)$ can be appreciated. This apparently complex relationship between the CP० of plagieclase and biotite becomes clarified by the numerical model (Fig. 10). The different aspect ratio of plagioclase with respect to biotite generates a faster evolution of the biotite fabric in this sample which has reached negative $\alpha$ values, while plagioclase $\alpha$ values remain positive. The measure values are coherent in the model with a $\gamma \approx 4$ (Fig. 10). Arbaret et al. (1996) demonstrated using analogue modelling the validity of the the ry for $\gamma$ values fr $\bullet-1 \bullet 5$, but for greater values, the number of interacting neighbouring crystals dramatically increases yielding results far from theoretical prediction. Taking inte account that the samples were selected because of their high intensity fabrics, the value of $\gamma \approx 4$ determined for $\mathrm{S} O 215$ cannot be extrap lated to the entire subvertical domain, because strain is heter geneous and this sample probably belongs to a highly deformed corridor where $y$ presents a maximum.

Sample SO222 shows a less defined CPO for plagi clase (Fig. 7) from which we cannot deduce any $\alpha$ angle. This was probably caused by the presence of the orthopyroxene in this sample, with an orthorhombic symmetry in respect to framework defined by the messcopic foliation and the SPO lineation. Nevertheless, biotite shows a very well def ined tiling of plagioclase with a positive value (considered positive because the tiling of biotite is coherent with the SPO moneclinic symmetry $\bullet$ btained for plagioclase). The biotite $\alpha$ angle is $11^{\circ}$, which indicates a shear strain $\gamma=2.8$ (Fig. 10). Sample SO224 shows a CPO with positive $\alpha$ angles for both plagioclase $\left(\alpha=7^{\circ}\right)$ and biotite $\left(\alpha=6^{\circ}\right)$ (Fig. 8) that are indicative of $\gamma \approx 3.5$ (Fig. 10). The $\bullet$ btained shear strain values of the subhorizental domain indicate mederate shearing against the upper subhorizental contact of the intrusion due to magmatic flow during magma entrance.

The model significantly differs from reality in a number of points: (1) it considers only $\bullet$ ne aspect rati for all the grains of a particular phase, (we have intrduced an average aspect ratio, but the reality is that different aspect ratios were found for the same phase), (2) the model begins with a initial stage characterized by a random orientation of all the grains and phases, but we know that some phases start to crystallize earlier than others and probably new grains were formed during the magmatic flew or deformation, se new random grains 
appeared during the shear evelution, (3) modelling does not consider the interaction between particles which is important during crystallization, (4) the model does not cønsider a pure shear cømpønent that prøbably tøok place in the subhorizontal domain, and (5) the model is -nly a 2D approximation of a 3D problem. Consequently the results $\bullet$ btaine from the comparisons of the textures in our samples with the numerical models have to be considered qualitative rather than quantitative. Nevertheless, we consider that this comparison is very useful taking inte account that the observed complex textures can be explained by the different velocity of rotation of the fabric of plagioclase and biotite, indicated by these very idealized models.

The role of biotite as a secondary fabric forming phase in plutons with mineraløgies including coarser phases such as plagieclase or K-feldspar makes its $\mathrm{CPO}$ complex and sometimes different the fabrics of the phenocrysts which are more easily oriented under different stress tensors. Our results clearly show that the preferred orientation of biotite is not always parallel to the main $\bullet$ bserved fabric (Figs. 5 and 6). For this reasen we argue that it is unwise to rely only on biotite CPOs measured indirectly using magnetic susceptibility anis tropy in order to characterize the fabrics of plutens without taking care to compare these results with the -rientation of coarser phases such as plagioclase or $\mathrm{K}$ feldspar. These differences could be explained by: rotation of fine crystals under simple shear, the facility to preserve relict fabrics or a combination of both mechanisms.

\section{Conclusions}

Magmatic fabrics are the result of cømplex prøcesses regarding magmatic flow, external tectonic strain, fluid dynamics, and the interaction between particles of different shapes and sizes included inte a melt. The application of EBSD to the understanding of magmatic fabrics has been demenstrated as a very useful technique. Using this technique for analyzing the subfabric of each mineral in plutons, can be very helpful for the interpretation of fabric origin and the emplacement mechanisms.

The natural samples analyzed here demenstrate that biotite fabrics are not always geod indicators of the main fabric of the røck when cøarser phases such as plagieclase are present. Special care shøuld be taken when magnetic susceptibility, which depends on the presence of paramagnetic minerals such as biotite, is the only technique used to constrain pluten fabrics in lith logies with coarser phases such as thøse seen in møst tenalites, quartzdiorites, gabbrøs, and feldspar-phyric granites. A comparisøn $\bullet$ magnetic susceptibility results with the fabrics $\bullet$ c coarser minerals is recommended, since coarser phases are better strain indicators than finer ones.

\section{Acknowledgements}

We would like to thank Patrick Launeau and PierreYves F. Robin for the creation and distribution of the freeware "Intercepts 2003", allowing us an easy application of the intercept methød to $\bullet$ ur samples. The research has been finance by Spanish grant PB98-0815. We would alsø like to thank Mike Hall, Schøol of GeoSciences, University of Edinburgh for his time an eff ort in preparing the samples prior to EBSD analysis.

\section{References}

Arbaret, L., Diot, H., Bouchez, J.L., 1996. Shape fabrics of particles in low concentration suspensions: 2 Dalogue experiments and application to tiling in magma. Joumal of Structural Geology 18, 941-950.

Arbaret, L., Fernandez, A., Jezek, J., Ildefonse, B., Launeau, P., Diot, H., 2000. Analogue and numerical modelling of shape fabrics: application to strain and flow detennination in magmas. Transactions of the Royal Society of Edinburgh. Earth Sciences 90, 97-109.

Bachiller, N., Galindo, C., Darbyshire, D.P.F., Casquet, C., 1997. Geocronología Rb-Sr de los leucogranitos \&el comple jo plutónico de Burguillos del Cerro (Badajoz). Geogaceta 21, 29-30.

Bascou, J., Camps, P., Dauria, J.M., 2005. Magnetic versus crystallographic fabrics in a basaltic lava flow. Joumal of Volcanology and Geothernal Research 145, 119-135.

Benn, K., Allard, B., 1989. Preferred mineral orientations related to magmatic flow in ophiolite layered gabbros. Journal of Petrology 30, $925-946$.

Beswnann, M., Prior, D.J., Veltkamp, K.T.A., 2004. Development of single-crys s-shaped quartz porphyroclasts by dissolution-precipitation creep in a calcite marble shear zone. Journal of Swuctural Geology 26, 869-883.

Blumenfeld, P., 1983. Le tuilage des mégacristaux, un critére d'écoulement rotationnel pour les fluidalités des roches magmatiques. Application au granite de Barbey-Séroux (Vosges, France). Bulletin de la Société Géologique de France 7, 309-318.

Blumenfeld, P., Bouchez, J.L., 1988. Shear criteria in grante and migmatite deforned in the magmatic and solid states. Journal of Swuctural Geology 10, 361-372.

Casquet, C., Galindo, C., Darbyshire, D.P.F., Noble, S.R., Tomos F., 1998. Fe-U-REE mineralization at Mina Monchi, Burguillos del Cerro, SW Spain. Age and isotope (U-P b, Rb-Sr and Sm-Nd) constints on the evolution of the ores. GAC-MAC-APGGQ Quebec' 98 Conf. Abstract 23, A-28.

Dallmeyer, R.D., García Casquero, J.L., Quesada, C., 1995. Ar/Ar mineral age constraints on the emplacement of the Burgillos del Cerro Igneous Complex (Ossa-Morena Zone, SW Iberia). Boletín Geológico y Minero 106, 203-214.

Eguiluz, L., Carracedo, M., Apalategui, O., 1989. Stock de Santa Olalla de Cala (Zona de Ossa-Morena, España). Stvdia Geologica Salmanticensia 4, 145-157. 
Fernandez, A., 1987. Preferred orientation developed by rigid markers in two-dimensional simple shear strain: a theoretical and experimental study. Tectonophysics 136, 151-158.

Fernandez, A., Feybesse, J.L., Mezure, J.F., 1983. Theoretical and experimental study of fabrics developed by different shaped marckers in two-dimensional simple shear. Bulletin de la Société Géologique de France 25, 319-326.

Fliervoet, T.F., Drury, M.R., Chopra, P.N., 1999. Crystallographic preferred orientations and misorientations in some olivine rocks deforned by diffusion or dislocation creep. Tectonophysics 303 , $1-27$.

Iezzi, G., Ventura, G., 2002. Crystal fabric evolution in lava flows: results fiom numerical simulations. Earth and Planetary Science Letters 200, 33-46.

Ildef onse, B., Launeau, P., Bouchez, J.L., Femandez, A., 1992. Effect of mechanical interactions on the development of shape preferred orien tions: a two-dimensional experiment approach. Joumal of Swuctural Geology 14, 73-83.

Jeffery, G.B., 1922. The motion of ellipsoidal particles immersed in a viscous fluid. Proceedings of the Royal Society of London 102, 161-179.

Jezek, J., Melka, R., Schulmann, K., Venera, Z., 1994. The behaviour of rigid riaxial ellipsoidal particles i viscous flows-modelling of fabric evolution in a multiparticle system. Tectonophysics 229, $165-180$.

Ji, S., Jiang, Z., Rybacki, E.W.R., Prior, D., Xia, B., 2004. Strain softening and micros uctural evolution of anorthite aggregates and quartz-anorthite layered composites deforned in torsion. Earth and Planetary Science Letters 222, 377-390.

Kameda, J., Yamagishi, A., Kogure, T., 2005. Morphological characteristics of ordered kaolinite; investigation using elecwon back-scattered diffiaction. American Mineralogist 90, 1462-1465.

Kogure, T., Bumno, M., 2004. Investigation of polytypes in lepidolite using electron back-scattere diffaction. American Mineralogist 89, 1680-1684.

Launeau, P., 2004. Mise en évidence des écoulements magmatiques par analyse d'images 2-D des distributions 3-D d'orientations préférentielles de fornes. Bulletin de la Société Géologique de France 175, 331-350

Launeau, P., Robin, P.-Y.F., 1996. Fabric analysis using the intercept method. Tectonophysics 267, 91-119

Llana-Fúnez, S., Rutter, E.H., 2005. Distribution of non-plane strain in experimental compression of short cylinders of Solnhofen limestone. Joumal of Smuctural Geology 27, 1205-1216.

Lunar, R., Ortega, L., Sierra, J., García Palomero, F., Moreno, T., Prichard, H., 1997. Ni-Cu (PGM) mineralization associated with mafic and ulramafic rocks: the recently discovered Aguablanca ore deposit, SW Spain. In: Papunen, H. (Ed.), Mineral Deposits. Balkema, Rotterdam, pp. 463-466.

Montero, P., Salman, K., Bea, F., Azor, A., Exposito, I., González Lodeiro, F., Martínez Poyatos, D., Simancas, J.F., 2000. New data on the geochronology of the Ossa-Morena Zone, Iberian Massif. Variscan-Appalachian dynamics: the building of the Upper Paleozoic basement. Basement Tectonics 15, 136-138

Ortega, L., Lunar, R., García-Palomero, F., Moreno, T., Martín Estevez, J.R., Prichard, H.M., Fisher, P.C., 2004. The Aguablanca Ni-Cu-PGE Deposit, Southwestem Iberia: magmatic ore-forning processes and retrograde evolution. Canadian Mineralogist 42, $325-335$.
Park, Y., Means, W.D., 1996. Direct observation of deformation processes in crystal mushes. Joumal of Smuctural Geology 18, 847-858.

Paterson, S.R., Vemon, R.H., Tobisch, O.T., 1989. A review of criteria for the identification of magmatic and tectonic foliations in granitoids. Journal of Suctural Geology 11, 349-363.

Paterson, S.R., Fowler, T.K., Schmidt, K.L., Yoshinobu, A.S., Yuan, E.S., Miller, R.B., 1998. Interpreting magmatic fabric patterns in plutons. Lithos 44, 53-82.

Pennock, G.M., Drury, M.R., Spiers, C.J., 2005. The development of subgrain misorientations with strain in dry synthetic $\mathrm{NaCl}$ measured using EBSD. Journal of Sructural Geology 27, $2159-2170$.

Pignotta, G.S., Benn, K., 1999. Magnetic fabric of the Barrington Passage pluton, Meguma Terrane, Nova Scotia: a two-stage fabric history of syntectonic emplacement. Tectonophysics 307, 75-92.

Piña, R., Lunar, R., Ortega, L., Gervilla, F., Alapieti, T., Martínez, C., 2006. Petrology and geochemis of mafic-ulmamafic fragments from the Aguablanca $\mathrm{Ni}-\mathrm{Cu}$ ore breccia, Southwest Spain. Economic Geology 101, 865-881.

Prior, D.J., Boyle, A.P., Brenker, F., Cheadle, M.C., Day, A., López, G., Peruzzo, L., Potts, G.J., Reddy, S., Spiess, R., Timms, N.E., Trimby, P., Wheeler, J., Zetterström, L., 1999. The application of electron backscatter diffraction and orientation con imaging in the SEM to textural problems in rocks. American Mineralogist 84, 1741-1759.

Romeo, I., Lunar, R., Capote, R., Quesada, C., Dunning, G.R., Piña, R., Ortega, L., 2006a. U/Pb age constraints on Variscan Magmatism and $\mathrm{Ni}-\mathrm{Cu}-\mathbf{P G E}$ metallogeny in the Ossa-Morena Zone (SW Iberia). Joumal of the Geological Society (London) 163 , 837-846

Romeo, I., Capote, R., Tejero, R., Lunar, R., Quesada, C., 2006b. Magma emplacement in wanspression: the Santa Olalla Igneous Complex (Ossa-Morena Zone, SW Iberia). Joumal of Swuctural Geology 28, 1821-1834

Romeo, I., Capote, R., Lunar, R., 2007a. Crystallographic preferred orientations and micros ucture of a Variscan marble mylonite in the Ossa-Morena Zone (SW Iberia). Joumal of Stuctural Geology 29, 1353-1368.

Romeo, I., Tejero, R., Capote, R., Lunar R., in press. 3D gravity modelling of the Aguablanca Stock, tectonic control and emplacement of a Variscan gabbronorite bearing a $\mathrm{Ni}-\mathrm{Cu}-\mathbf{P G E}$ ore, SW Iberia. Geological Magazine.

Tikoff; B., Teyssier, C., 1994. Strain and fabric analyses based on porphyroclast interaction. Joumal of Sructural Geology 16, 477-491.

Tomos, F., Casquet, C., Galindo, C., Canales, A., Velasco, F., 1999. The genesis of the variscan ul wamafic-hosted magmatic $\mathrm{Cu}-\mathrm{Ni}$ deposit of Aguablanca, SW Spain. In: Stanley, et al. (Ed.), Mineral Deposits: Processes to Processing. Balkema, Rotterdam, pp. 795-798.

Tomos, F., Casquet, C., Galindo, C., Velasco, F., Canales, A., 201. A new style of $\mathrm{Ni}-\mathrm{Cu}$ mineralization related to magmatic breccia pipes in a manspressional magmatic arc, Aguablanca, Spain. Mineralium Deposita 36, 700-706.

Vernon, R.H., Jolunson, S.E., Melis, E.A., 2004. Emplacement-related micros uctures in the margin of a deformed pluton: the San José tonalite, Baja Califomia, México. Journal of Smuctural Geology 26, 1867-1884.

Willis, D.G., 1977. A kinematic model of preferred orientation. Geological Society of America Bulletin 88, 883-894. 